\title{
Analyses of impacts of China's international trade on its water resources and uses
}

\author{
Z. Y. Zhang ${ }^{1,2}$, H. Yang ${ }^{3}$, M. J. Shi ${ }^{1,2}$, A. J. B. Zehnder ${ }^{4,5}$, and K. C. Abbaspour ${ }^{3}$ \\ ${ }^{1}$ Graduate University of Chinese Academy of Sciences, 100049, Beijing, China \\ ${ }^{2}$ Research Centre on Fictitious Economy \& Data Science, Chinese Academy of Sciences, 100190, Beijing, China \\ ${ }^{3}$ Swiss Federal Institute of Aquatic Science and Technology, 8600, Dübendorf, Switzerland \\ ${ }^{4}$ Nanyang Technological University (NTU), 639798, Singapore \\ ${ }^{5}$ Alberta Water Research Institute (AWRI), Edmonton, AB T5N 1M9, Canada
}

Received: 24 March 2011 - Published in Hydrol. Earth Syst. Sci. Discuss.: 12 April 2011

Revised: 14 August 2011 - Accepted: 24 August 2011 - Published: 14 September 2011

\begin{abstract}
This study provides an insight into the impact of China's international trade of goods and services on its water resources and uses. Virtual water flows associated with China's international trade are quantified in an input-output framework. The analysis is scaled down to the sectoral and provincial levels to trace the origins and destinations of virtual water flows associated with the international trade. The results show that China is a net virtual water exporter of $4.8 \times 10^{10} \mathrm{~m}^{3} \mathrm{yr}^{-1}$, accounting for $2.1 \%$ of its renewable water resources and $8.6 \%$ of the total water use. Water scarce regions tend to have higher percentages of virtual water export relative to their water resources and water uses. In the water scarce Huang-Huai-Hai region, the net virtual water export accounts for $8.0 \%$ of the region's water resources and $11.3 \%$ of its water uses. For individual sectors, major net virtual water exporters are those where agriculture provides raw materials in the initial process of the production chain. The results suggest that China's economic gains from being a world "manufacture factory" have come at a high cost to its water resources.
\end{abstract}

\section{Introduction}

International trade between countries entails flows of virtual water, i.e. the water used for the production of traded products (Allan, 1993; Hoekstra and Hung, 2005; Yang et al., 2006; Hoekstra, et al., 2009). An inflow of virtual water through trade reduces the pressure on domestic water resources, whereas an outflow of virtual water adds to the

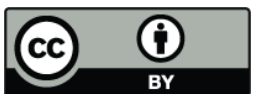

Correspondence to: $\mathrm{H}$. Yang (hong.yang@eawag.ch) pressure. With the world markets flooded with "made in China" products on the one hand and the increasingly severe water stress and pollution endured in most parts of China on the other, the impact of China's international trade of goods and services on its water resources and uses warrants a scrutiny.

Significant literature exists on the role of virtual water trade in addressing water scarcity and in redistributing water resources (virtually) (Yang and Zehnder, 2002; Yang et al., 2003; Oki and Kanae, 2004; Hoekstra and Hung, 2005; Yang et al., 2006; Hoekstra and Chapagain, 2007; Guan and Hubacek, 2007; Liu et al., 2007; Chapagain and Hoekstra, 2008). Studies on the relevant issues have hitherto mostly concerned with agricultural products due to their high water intensity in production and large share in total water use. For instance, Yang and Zehnder (2002) estimated the volume of virtual water embedded in food imports into the countries in the southern Mediterranean region. They highlighted that food imports were imperative for compensating water resources deficiency in these countries. The major components of the virtual water flows were investigated at the global level by Zimmer and Renault (2003). This analysis was further refined by Hoekstra and Hung (2005). They quantified the volumes of virtual water flows between nations related to international crop trade and analyzed virtual water balance in relation to national water needs and water availability. Yang et al. (2006) assessed the efficiency of the water use embodied in the international food trade from the perspectives of exporting and importing countries. Hoekstra and Chapagain (2007) and Chapagain and Hoekstra (2008) examined the water consumption in individual countries with distinction of internal and external water sources. The results showed that worldwide, about $16 \%$ of the water use is for the production of goods and services that are for export.

Published by Copernicus Publications on behalf of the European Geosciences Union. 
Recent years have seen some studies extending the assessment of virtual water flows associated with the international trade to all the sectors of an economy. Zhao et al. (2009) quantified China's virtual water trade for each individual sector using an input-output model. They found that China as a whole is a net virtual water exporter, although the agricultural sector is a net importer. However, they did not specify the origin and destinations of the virtual water and the impact on water uses at the regional level. Using a similar approach, Dietzenbacher and Velazquez (2007) assessed the virtual water embodied in the trade of 25 sectors in the Andalusian economy system and the findings reveal Andalusia as a net virtual water exporter. So far, however, studies on virtual water flows associated with international trade of all the sectors in a national economy are limited.

There are a number of gaps lying in the previous studies of virtual water flows associated with the international trade. One is the overwhelming focus on agricultural products and little attention to other sectors of an economy. Secondly, most of the studies have been conducted at the country level or for a single region. For a country like China which is vast in territory and uneven in water resources distribution, treating the country as a whole overlooks the regional variations in water endowments and the impacts of virtual water trade on regional water resources and uses. A sub-country study is more pertinent to reflect the specific local conditions and regional water problems. Thirdly, the hitherto literature generally lacks the specification of the origins of the virtual water export and the destinations of the virtual water import within a country. The specification of the origins/destinations of the virtual water export/import is important for identifying the prominent regions influencing national virtual water trade patterns and the regions where water resources and uses are significantly affected by their international trade patterns.

This paper aims to quantify the virtual water flows associated with China's international trade of goods and services in a framework of the input-output model. All the economic sectors in the national economy are considered in the assessment. The analysis is scaled down to the provincial level to specify the impact of virtual water trade of individual economic sectors on water resources and uses across regions. The results of this study contribute to a better understanding of China's water problems and provide scientific bases for supporting policies to alleviate the negative impact of its international trade on water resources and uses in different regions.

\section{Data and methodology}

\subsection{Data}

The main data foundation of this study is the 2002 regional input-output tables of 30 provinces, autonomous regions and municipalities in mainland China (National Bureau of
Statistics of China, 2008). Tibet is not included due to data unavailability. For simplicity, these 30 administrative entities are all called provinces in this study. Considering the sector correspondence between regional input-output tables and the data of sectoral direct freshwater use, the $60 \mathrm{sec}-$ tors in the original provincial input-output tables are aggregated into 20 sectors (Table 1). The basic data in determining the direct freshwater uses per monetary unit of production, called direct water use coefficient (DWUC, $\mathrm{m}^{3} /$ Yuan) (1 Yuan $\approx 0.16$ USD), are taken from Zhao et al. (2009).

In this study, water resources, water uses and virtual water trade concern only blue water, i.e. the surface and ground water. Soil moisture, the so-called green water is not considered. The definition of blue and green water follows that by Falkenmark and Rockström (2006). The exclusion of green water is mainly for the content consistency of water use across economic sectors. Except for the agricultural sector and the sectors where agriculture provides raw materials in the production processes, all the other sectors use exclusively blue water, the opportunity cost of which is high due to the possibility of choosing alternative water sources. Green water use is typically $60-80 \%$ of the water use in the agricultural sector. Including green water in water use accounting greatly increases the share of agricultural water use in total water use. Mixing blue and green water in the analysis could derive misleading conclusions in assessing the efficiency in water resources utilization across regions and among different sectors.

The scope of the water use in this study follows the definition used in China's official statistics (China Statistical Yearbook). The water use in the industrial sectors refers to the freshwater intake during the whole production process. The recycling and reuse of the water within the system is not included in the water use. In the agricultural sector, the water use is the irrigation water supply to the field.

In both the agriculture and industrial sectors, part of the water used is returned to the natural water systems through percolation and/or drainage and wastewater discharge. Considering that the return flow from agriculture may be available for downstream users, the calculation of the agricultural water use and virtual water trade deducted the return flow by multiplying the direct water use coefficient with the water consumptive use ratio available from the Water Resources Bulletin of the six major river basins (Haihe, Huaihe, Yellow River, Yangzi, Pearl River, Songliao River (River Basin Water Conservancy Commissions, 2008). In the industrial sectors, the wastewater discharge is not deducted from the industrial water use because the polluted water may not be used again without treatment. Besides, lacking information on the actual discharge rate and the pollution intensity in each industrial sector also adds difficulties in considering the return flows. Neglecting return flows in the industrial sectors in the calculation of virtual water flows is also seen in other studies, e.g. Hoekstra and Chapagain, 2007; Yu et al., 2010; Zhao et al., 2010. 
Table 1. Detailed results of sectoral virtual water trade accounting (2002).

\begin{tabular}{|c|c|c|c|c|c|c|c|}
\hline & \multirow{3}{*}{ Sectors } & \multirow{2}{*}{$\begin{array}{r}\text { DWUC } \\
\omega_{j} \\
\end{array}$} & $\begin{array}{r}\text { TWUC } \\
\text { (Average) }\end{array}$ & \multirow{2}{*}{$\begin{array}{r}\text { Virtual } \\
\text { Export } \\
u_{j} \\
\end{array}$} & \multirow{2}{*}{$\begin{array}{r}\text { Virtual } \\
\text { Import } \\
v_{j} \\
\end{array}$} & \multirow{2}{*}{$\begin{array}{r}\text { Net Virtual } \\
\text { Water Export } \\
u_{j}-v_{j}\end{array}$} & \multirow{2}{*}{$\begin{array}{r}\text { Water use } \\
\text { for final demand } \\
t_{j}\end{array}$} \\
\hline & & & $\delta_{j}$ & & & & \\
\hline & & $\mathrm{m}^{3} 10^{-4}$ Yuan $^{-1}$ & $\mathrm{~m}^{3} 10^{-4}$ Yuan $^{-1}$ & $10^{6} \mathrm{~m}^{3} \mathrm{yr}^{-1}$ & $10^{6} \mathrm{~m}^{3} \mathrm{yr}^{-1}$ & $10^{6} \mathrm{~m}^{3} \mathrm{yr}^{-1}$ & $10^{6} \mathrm{~m}^{3} \mathrm{yr}^{-1}$ \\
\hline 1 & Agriculture & 915 & 1187 & 5589 & 7855 & -2265 & 101974 \\
\hline 2 & Coal mining and processing & 32 & 230 & 355 & 45 & 309 & 662 \\
\hline 3 & Food and tobacco processing & 32 & 758 & 6199 & 3791 & 2409 & 64691 \\
\hline 4 & Textile goods & 30 & 563 & 13824 & 1164 & 12660 & 3747 \\
\hline 5 & Clothing & 6 & 419 & 9575 & 1035 & 8541 & 11203 \\
\hline 6 & Sawmills and furniture & 3 & 453 & 3118 & 548 & 2571 & 4066 \\
\hline 7 & Paper and products & 90 & 430 & 3849 & 883 & 2966 & 2632 \\
\hline 8 & Petroleum processing & 25 & 308 & 1086 & 2719 & -1633 & 478 \\
\hline 9 & Chemicals & 48 & 353 & 7511 & 4558 & 2953 & 6528 \\
\hline 10 & Non-metal mineral products & 23 & 534 & 3085 & 830 & 2255 & 4051 \\
\hline 11 & Metal smelting and products & 41 & 614 & 9207 & 4611 & 4596 & 5279 \\
\hline 12 & Machinery and equipment & 5 & 221 & 2846 & 6615 & -3769 & 18321 \\
\hline 13 & Transport equipment & 6 & 217 & 1584 & 1572 & 12 & 5180 \\
\hline 14 & $\begin{array}{l}\text { Electric equipment, } \\
\text { telecommunication equipment }\end{array}$ & 3 & 207 & 14052 & 5856 & 8195 & 11437 \\
\hline 15 & Other manufacturing & 5 & 250 & 3363 & 2003 & 1360 & 2997 \\
\hline 16 & $\begin{array}{l}\text { Electricity, gas and water } \\
\text { production and supply }\end{array}$ & 814 & 1043 & 67 & 3956 & -3889 & 15216 \\
\hline 17 & Construction & 4 & 228 & 193 & 144 & 49 & 61042 \\
\hline 18 & $\begin{array}{l}\text { Wholesale and retail trade and } \\
\text { passenger transport }\end{array}$ & 40 & 188 & 7075 & 380 & 6695 & 13114 \\
\hline 19 & Restaurant and hotel & 170 & 640 & 2187 & 22 & 2165 & 16703 \\
\hline \multirow[t]{2}{*}{20} & Other services & 23 & 168 & 3826 & 2360 & 1466 & 50715 \\
\hline & Total & & & 98591 & 50945 & 47646 & 400034 \\
\hline
\end{tabular}

DWUC: direct water use coefficient; TWUC: total water use coefficient

We would like to emphasize that the motivation of this study, as stated in the title, is to explicitly address the impact of China's international trade on the water resources and uses in individual provinces. The intra-country trade is beyond the scope of this study. However, we are aware of the importance of the intra-national virtual water trade in regional water balances. An interregional Input-Output tables-based analysis of interregional virtual water trade shall be conducted in a separate paper.

\subsection{Methodology}

\subsubsection{The basic mathematical structure of the input-output model}

Input-output table/model, firstly developed by Leontief (1941), represents the monetary transactions of goods and services among different sectors of economic system. It provides a technique to specify how the substances flow among sectors through supplying inputs (including water) for the outputs (where the virtual water is embedded) in the economic system. Since the information on interconnections and interdependences of economic units is essential to the determination of the virtual water content of a product, the input-output model is a practical tool in the virtual water trade estimation.

The basic mathematical structure of the input-output system consists of $n$ linear equations as shown in Eq. (1), depicting how the productions of an economy depend on intersectoral relationships and final demand.

$x_{i}=\sum_{j=1}^{n} x_{i j}+y_{i}$

where $n$ is the number of economic sectors; $x_{i}$ is the total output of sector $i ; x_{i j}$ is the inter-sectoral monetary flows from sector $i$ to sector $j . y_{i}$ is the final demand of sector $i$.

The direct input refers to the input provided by a sector for the production of another sector in the last stage of the production chain and it numerically equals to the elements of the inter-sectoral flow matrix (i.e. $x_{i j}$ is the direct input from sector $i$ to sector $j$ ). The direct input coefficient $\alpha_{i j}$ indicates the amount of input from sector $i$ required to increase one monetary unit output of sector $j$ (Eq. 2).

$\alpha_{i j}=\frac{x_{i j}}{x_{j}}$ 
Therefore, Eq. (1) can be rewritten so as to include the direct input coefficient $\alpha_{i j}$ :

$x_{i}=\sum_{j=1}^{n} \alpha_{i j} x_{j}+y_{i}$

Equation (3) can be shown as follows in matrix notation:

$\mathbf{X}=\mathbf{A X}+\mathbf{Y}$

where $\mathbf{X}, \mathbf{A}$ and $\mathbf{Y}$ are respectively the matrices of output, direct input coefficients and final demand.

Assuming the matrix $\mathbf{A}$ of direct input coefficients is constant, it is possible to change Eq. (4) into a demand-driven format:

$\mathbf{X}=(\mathbf{I}-\mathbf{A})^{-1} \mathbf{Y}, B=(\mathbf{I}-\mathbf{A})^{-1}=\left[b_{i j}\right]$

where $(\mathbf{I}-\mathbf{A})^{-1}$ is known as the Leontief inverse matrix; $b_{i j}$ denotes how much output of sector $i$ is required to meet one monetary unit of the final demand of sector $j$. Thus, the link between final demand and corresponding direct and indirect production has been built up with the Leontief inverse matrix as the bridge.

\subsubsection{Direct water use coefficient and total water use coefficient}

In order to combine the monetary trade with the associated water use, the essential step is to derive direct water use coefficient (DWUC), the amount of direct water intake to produce one monetary unit of output, representing the direct or the first round effects of the sectoral interaction in the economy (Bouhia, 2001; Hubacek and Sun, 2005). DWUC can be expressed as Eq. (6).

$\mathbf{W}=\left[\omega_{j}\right], \omega_{j}=\frac{w_{j}}{x_{j}}$

where $\mathbf{W}$ is the matrix of DWUC (measured in $\mathrm{m}^{3} 10^{-4}$ Yuan $^{-1}$ in this study); $\omega_{j}$ is the DWUC of sector $j ;\left(\omega_{j}\right)$ is calculated by dividing the water use of sector $j\left(w_{j}\right)$ by total output of sector $j\left(x_{j}\right)$ (in monetary term).

The total water use coefficient (TWUC) $\delta_{j}$ (measured in $\mathrm{m}^{3} 10^{-4}$ Yuan $^{-1}$ ), an indicator of the total water consumption throughout the whole production chain, can be achieved by multiplying DWUC $\omega_{j}$ with the Leontief inverse matrix $\left[b_{i j}\right]$.

$\mathbf{D}=\left[\delta_{j}\right], \delta_{j}=\sum_{i} \omega_{i} \times b_{i j}$

where $\mathbf{D}$ is the matrix of TWUC, which links the monetary product trade with their corresponding total amount of water use.

\subsubsection{The water use to meet domestic final demand}

The water use to meet domestic final demand can be obtained by multiplying TWUC with final demand:

$\mathbf{T}=\left[t_{j}^{S}\right], \quad t_{j}^{s}=\delta_{j}^{S} \cdot y_{j}^{S}$

where $\mathbf{T}$ (measured in $10^{6} \mathrm{~m}^{3} \mathrm{yr}^{-1}$ ) is the matrix of water use for domestic final demand; $t_{j}^{s}$ is the water use for final demand of sector $j$ in region $S ; \delta_{j}^{S}$ is the TWUC of sector $j$ in region $S ; y_{j}^{S}$ is the final demand of sector $j$ in region $S$.

\subsubsection{Virtual water trade accounting}

In the virtual water trade analysis, the virtual water export can be obtained through Eq. (9).

$\mathbf{U}=\left[u_{j}^{S}\right], \quad u_{j}^{S}=\delta_{j}^{S} \times e_{j}^{S}$

where $\mathbf{U}$ is the matrix of the virtual water export (measured in $\left.10^{6} \mathrm{~m}^{3} \mathrm{yr}^{-1}\right) ; u_{j}^{S}$ is the virtual water export of sector $j$ in region $S ; \delta_{j}^{S}$ is the TWUC of sector $j$ in region $S ; e_{j}^{S}$ is the export of sector $j$ in region $S$.

The regional input-output tables used in this study are characterized as import-competitive. The underlying assumption is that the import is competitive with domestic supplies and thus can be incorporated into domestic supplies of final demand as well as the intermediate demand. The import consisting of the two parts can be expressed as:

$m_{j}^{S}=m_{j}^{S(\mathrm{in})}+m_{j}^{S(\mathrm{f})}$

where $m_{j}^{S}$ is the total import of sector $j$ in region $S ; m_{j}^{S(\text { in) }}$ is the import for the intermediate demand of sector $j$ in region $S ; m_{j}^{S(\mathrm{f})}$ is the import for the final demand of sector $j$ in region $S$. The two parts are determined according to the distributing proportions of the intermediate demand and final demand in the composition of the total demand.

Thus, $v_{j}^{S(\mathrm{f})}$, the virtual water imported for final demand, can be obtained by multiplying the import incorporated in final demand $m_{j}^{S(\mathrm{f})}$ with the corresponding TWUC $\delta_{j}^{S}$ as shown in Eq. (11).

$v_{j}^{S(\mathrm{f})}=\delta_{j}^{S} \cdot m_{j}^{S(\mathrm{f})}$

While the virtual water imported for intermediate use and consumed by domestic final demand can be derived through Eq. (12):

$v_{j}^{S(\mathrm{in})}=\delta_{j}^{S} \cdot m_{j}^{S(\mathrm{in})} \cdot \eta_{j}^{S}$

where $\eta_{j}^{S}$ is an adjusting coefficient derived as the proportion of the outcome of final demand minus export over the final demand of final demand, representing that only a portion of virtual water embodied in intermediate input will be used for domestic final demand. 
The virtual water import with the two parts can be obtained as:

$\mathbf{V}=\left[v_{j}^{S}\right], \quad v_{j}^{S}=v_{j}^{S(\text { in })}+v_{j}^{S(\mathrm{f})}$

where $\mathbf{V}$ is the matrix of virtual water import (measured in $\left.10^{6} \mathrm{~m}^{3} \mathrm{yr}^{-1}\right) ; v_{j}^{S}$ is the virtual water import of sector $j$ in region $S ; v_{j}^{S(\text { in) }}$ is the virtual water import for intermediate demand of sector $j$ in region $S ; v_{j}^{S(\mathrm{f})}$ is the virtual water import for final demand of sector $j$ in region $S$.

\section{Results}

\subsection{Virtual water import and export in individual sectors}

DWUC reflects the direct water intensity at the last stage of the production chain, whereas TWUC reflects the water intensity throughout the whole production chain. Using Eqs. (6) and (7), DWUC and TWUC for each sector are calculated. The virtual water import and export in each sector are derived by multiplying the import and export values with TWUC (Table 1).

TWUC is higher than DWUC in all the sectors. This is expected because DWUC only accounts for the water use at the last stage of the production chain, whereas TWUC is the accumulated water use in the whole production chain.

Sector 1 (agriculture) has the highest water-intensity, with DWUC of $915 \mathrm{~m}^{3} 10^{-4}$ Yuan $^{-1}$ and TWUC of $1187 \mathrm{~m}^{3} 10^{-4}$ Yuan $^{-1}$. This is followed by Sector 16 (electricity, gas and water production and supply) where DWUC and TWUC are $814 \mathrm{~m}^{3} 10^{-4}$ Yuan $^{-1}$ and $1043 \mathrm{~m}^{3} 10^{-4}$ Yuan $^{-1}$, respectively. It is noticed that the difference between DWUC and TWUC in these two sectors are relatively small in comparison to the differences in other sectors. The high DWUC indicates that the direct water use is the major form of water use in Sector 1 and Sector 16. In contrast, most manufacturing industry sectors have large indirect water consumption. For manufacturing sectors like Sector 3 (food and tobacco processing), Sector 4 (textile goods), Sector 5 (clothing), Sector 6 (sawmills and furniture) and Sector 10 (non-metal mineral products), the shares of the direct water use in the total water use of the whole production chain are lower than $5 \%$. Hence, over $95 \%$ of the water use in these sectors occurred in an indirect way, i.e. in the previous processing stages prior to the final stage.

The total amount of virtual water import is $5.1 \times 10^{10} \mathrm{~m}^{3} \mathrm{yr}^{-1}$, whereas the total virtual water export is $9.9 \times 10^{10} \mathrm{~m}^{3} \mathrm{yr}^{-1}$. Hence, China turns out to be a net virtual water exporter of $4.8 \times 10^{10} \mathrm{~m}^{3} \mathrm{yr}^{-1}$ in view of the whole national economy.

For individual sectors, the virtual water trade balance varies. Sector 1 (agriculture), Sector 8 (petroleum processing), Sector 12 (machinery and equipment) and Sector 16

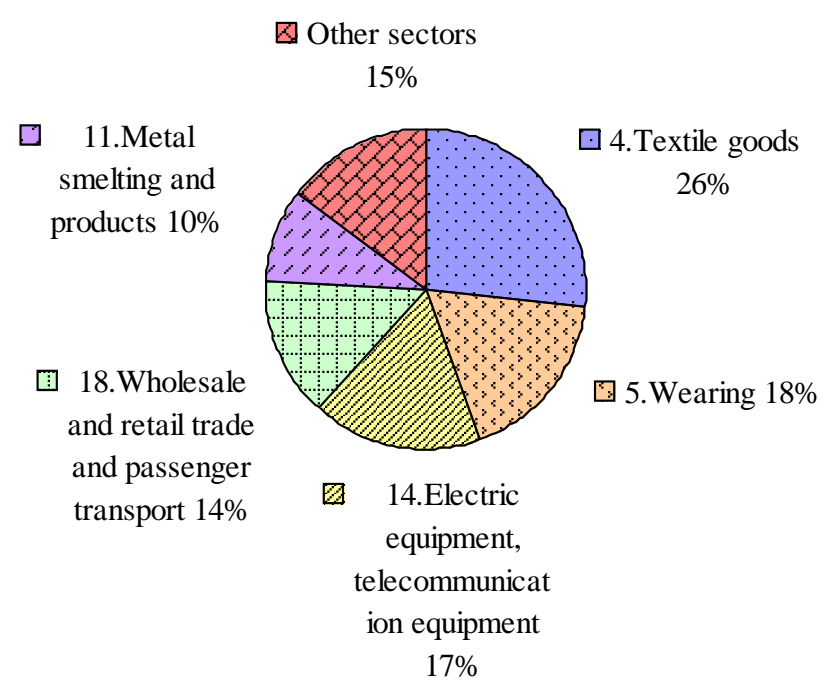

Fig. 1. Shares of the major net virtual water exporting sectors in total net virtual water export (2002).

(electricity, gas and water production and supply) are the net importers of virtual water. The other 16 sectors are net exporters.

Sector 4 (textile goods), Sector 5 (clothing), Sector 14 (electric equipment, telecommunication equipment), Sector 18 (wholesale and retail trade and passenger transport) and Sector 11 (metal smelting and products) are the five major net virtual water exporters (Fig. 1). These sectors are the mainstay industries in China, greatly contributing to China's role as the "world manufacturing factory". Their total net virtual water export amounts to $4.1 \times 10^{10} \mathrm{~m}^{3} \mathrm{yr}^{-1}$, or $85.4 \%$ of the total net virtual water export of the country.

The ratio of the net virtual water export to water use for domestic final demand indicates how the water use is distributed between domestic demand and external (abroad) demand (export). At the national level, the ratio is $11.9 \%$, indicating that a considerable amount of water use in China is for the production of goods and services for export.

Sector 4 (textile goods) has the highest ratio of net virtual water export to water use for final demand, $337.9 \%$ (Fig. 2). This suggests that the textile goods are mostly exported to other countries. Besides, Sector 7 (paper and products), Sector 11 (metal smelting and products) and Sector 5 (clothing) are also of high ratios, respectively $112.7 \%, 87.1 \%$ and $76.2 \%$. Sector 8 (petroleum processing) is the major net virtual water importer with the ratio of $-341.9 \%$. Petroleum, an important intermediate material for industries, is badly needed to support the continuous economic growth in China. The domestic production is far short to meet the demand. The dependence on import is large and increasing over the years. 


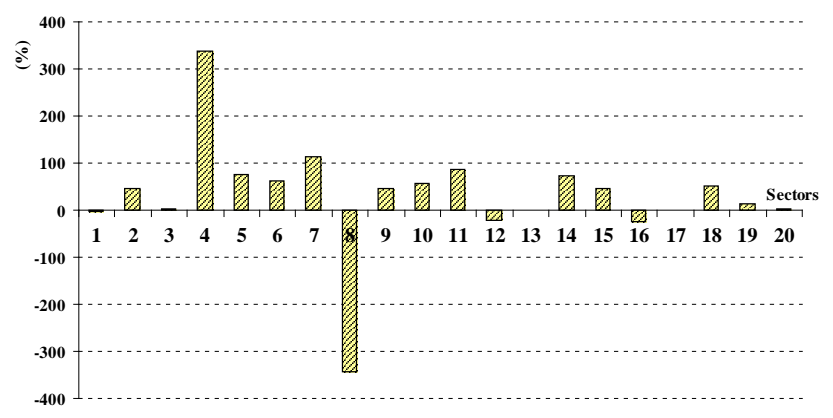

Fig. 2. Ratios of net virtual water export to water use for domestic final demand in different sectors (2002).

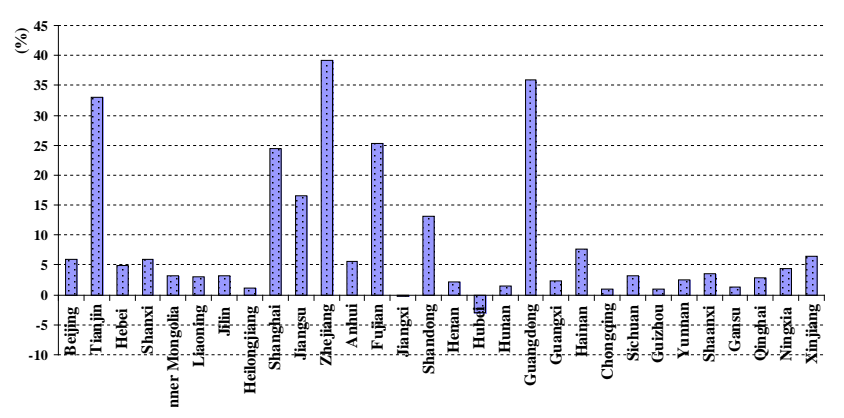

Fig. 3. Ratios of net virtual water export to water use for final demand in individual provinces (2002).

\subsection{Regional variations in virtual water trade}

With significant discrepancies in natural conditions and economic development levels among regions, the virtual water trade patterns also appear to show spatial variations. Table 2 provides the quantity of virtual water trade of individual provinces associated with their international trade of final products.

Except for Jiangxi and Hubei, all the other provinces are net virtual water exporters (Fig. 2, Table 2). Guangdong is the largest net virtual water exporter with the net virtual water export of $1.4 \times 10^{10} \mathrm{~m}^{3} \mathrm{yr}^{-1}$, accounting for $29.7 \%$ of the total net virtual water export of China. Zhejiang, Jiangsu, and Shandong are also important virtual water exporters, accounting for the total net virtual water export of $17.8 \%$, $12.9 \%$, and $9.2 \%$, respectively.

With two exceptions, all other provinces are net virtual water exporters (Fig. 2, Table 2). Some provinces have very high ratios of net virtual water export to water use for final demand in individual provinces (Fig. 3), implying an export oriented economy. The ratio of Zhejiang is $39 \%$, the highest among all the provinces. Generally, the provinces in the Eastern Coastal area of China have relatively higher ratios of net virtual water export to water use for final demand in individual provinces, consistent with their roles as the major contributors of the national economy and export in China.
Table 2. Virtual water trade at the provincial level (2002) $\left(10^{6} \mathrm{~m}^{3} \mathrm{yr}^{-1}\right)$.

\begin{tabular}{|c|c|c|c|c|}
\hline & \multirow[t]{2}{*}{ Provinces } & \multirow{2}{*}{$\begin{array}{r}\begin{array}{r}\text { Virtual } \\
\text { water export }\end{array} \\
10^{6} \mathrm{~m}^{3} \mathrm{yr}^{-1}\end{array}$} & \multirow{2}{*}{$\begin{array}{r}\begin{array}{r}\text { Virtual } \\
\text { water import }\end{array} \\
10^{6} \mathrm{~m}^{3} \mathrm{yr}^{-1}\end{array}$} & \multirow{2}{*}{$\begin{array}{r}\begin{array}{r}\text { Net virtual } \\
\text { water export }\end{array} \\
10^{6} \mathrm{~m}^{3} \mathrm{yr}^{-1}\end{array}$} \\
\hline & & & & \\
\hline 1 & Beijing & 2064 & 1497 & 567 \\
\hline 2 & Tianjin & 2351 & 961 & 1390 \\
\hline 3 & Hebei & 1700 & 905 & 795 \\
\hline 4 & Shanxi & 769 & 282 & 488 \\
\hline 5 & Inner Mongolia & 596 & 342 & 254 \\
\hline 6 & Liaoning & 5945 & 5401 & 544 \\
\hline 7 & Jilin & 887 & 606 & 281 \\
\hline 8 & Heilongjiang & 913 & 803 & 110 \\
\hline 9 & Shanghai & 7602 & 4679 & 2924 \\
\hline 10 & Jiangsu & 13030 & 6884 & 6146 \\
\hline 11 & Zhejiang & 10563 & 2063 & 8500 \\
\hline 12 & Anhui & 1136 & 479 & 657 \\
\hline 13 & Fujian & 6130 & 2293 & 3838 \\
\hline 14 & Jiangxi & 557 & 577 & -20 \\
\hline 15 & Shandong & 10348 & 5979 & 4369 \\
\hline 16 & Henan & 1607 & 980 & 627 \\
\hline 17 & Hubei & 818 & 1257 & -439 \\
\hline 18 & Hunan & 707 & 490 & 217 \\
\hline 19 & Guangdong & 25734 & 11604 & 14130 \\
\hline 20 & Guangxi & 581 & 348 & 233 \\
\hline 21 & Hainan & 324 & 129 & 195 \\
\hline 22 & Chongqing & 494 & 414 & 80 \\
\hline 23 & Sichuan & 1025 & 453 & 572 \\
\hline 24 & Guizhou & 296 & 234 & 63 \\
\hline 25 & Yunnan & 657 & 400 & 257 \\
\hline 26 & Shaanxi & 638 & 361 & 277 \\
\hline 27 & Gansu & 289 & 207 & 82 \\
\hline 28 & Qinghai & 56 & 18 & 38 \\
\hline 29 & Ningxia & 127 & 51 & 75 \\
\hline \multirow[t]{2}{*}{30} & Xinjiang & 644 & 249 & 395 \\
\hline & Total & 98591 & 50945 & 47646 \\
\hline
\end{tabular}

\subsection{Sectoral virtual water trade in selected water scarce provinces}

Water resources endowments vary across provinces in China. Provinces in the north in general are water scarce. It is interesting to take a closer look at the virtual water trade patterns of the water scarce provinces to gain some insights into the impact of the international trade on their water resources. Figure 4 shows the major exporting sectors in 4 extreme water scarce provinces, Beijing, Tianjin, Hebei, and Shandong. The per capita renewable water resources availability in these provinces is lower than $150 \mathrm{~m}^{3} /$ capita, far below the internationally recognized minimum standard of $1000 \mathrm{~m}^{3} /$ capita (Wang and Wang, 2005). The net virtual water export in these 4 provinces accounts for $14.9 \%$ of the total net virtual water export of China, whereas the sum of their water resources is only $2.2 \%$ of the national total.

Figure 4 presents the share of the first 5 major net virtual water exporting sectors in total net virtual water export in the 
Beijing

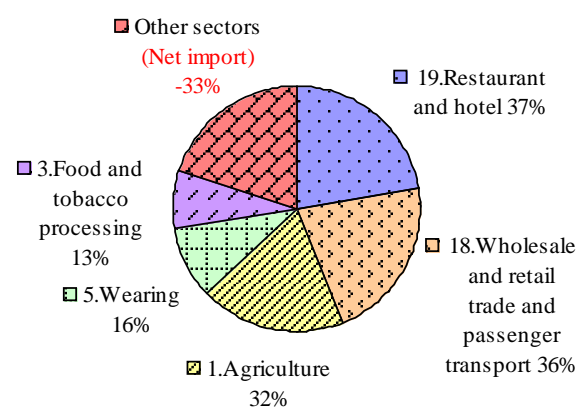

Hebei

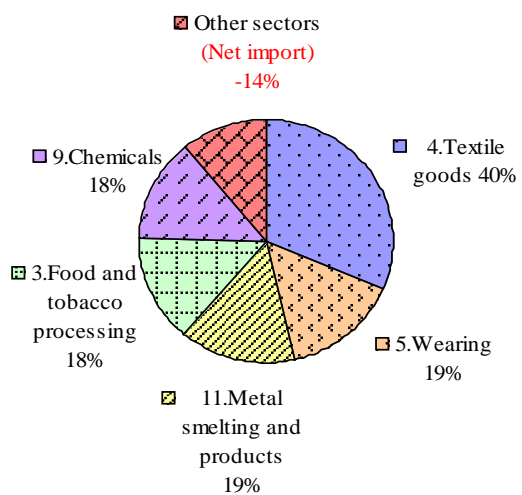

Tianjin

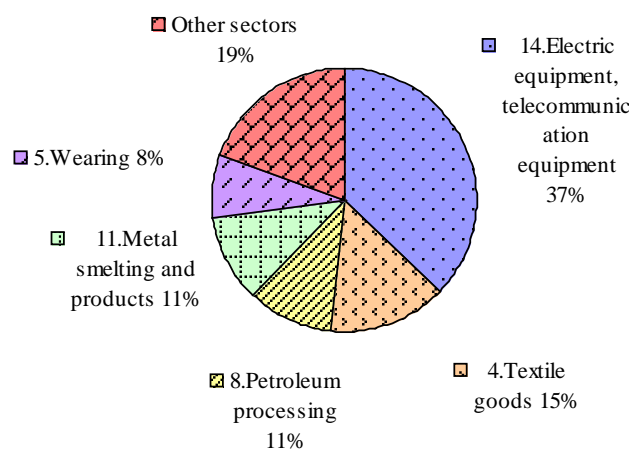

Shandong

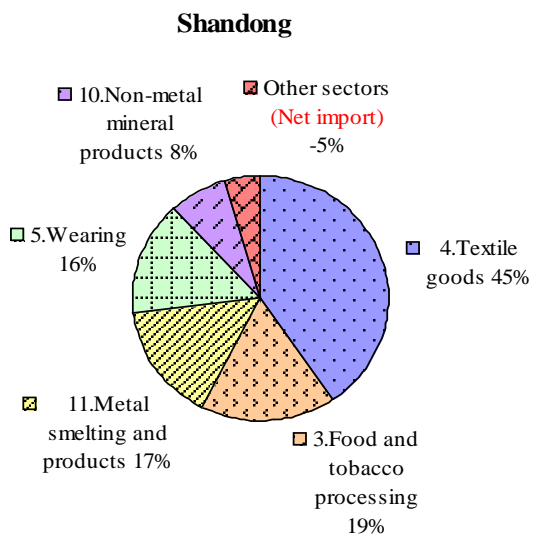

Fig. 4. The major net virtual water exporting sectors in the selected water scarce provinces (2002).

selected provinces. Apart from Sector 4 and Sector 5 (textile and clothing sectors), there are significant variations in other major sectors in the selected provinces. They reflect the sectoral specialization in these provinces. For example, the net virtual water export in Beijing mainly concentrates in the sectors related to services (Sector 18 and Sector 19). The virtual water export of services refers to the water used in providing services to the people coming from outside China. As Beijing is the capital city visited by many foreigners every year, the service related sectors are the main contributors to its virtual water export. In Tianjin, Sector 14 (electrical goods and communication equipments) and Sector 8 (petroleum processing) have large shares in net virtual water export. The large net virtual water export in Sector 8 corresponds to Tianjin's role as one of the most important petroleum production bases in China. Tianjin's advantage in port transportation conditions facilitates the export of petroleum products. In Shandong, the net virtual water export is highly concentrated in the five major exporting sectors. The share of the remaining sectors is $-5 \%$, meaning that the net virtual water import in these sectors offsets $5 \%$ of the net virtual water export in the province.

\section{Discussion}

\subsection{The scale of virtual water export and impact on domestic water resources}

The results confirm the earlier findings that China is a net virtual water exporter. Given the total water resources of $2.2 \times 10^{12} \mathrm{~m}^{3} \mathrm{yr}^{-1}$ (average of 2002-2008), the net virtual water export is about $2.1 \%$ of the total water resources of the country. This is seemingly a small percentage. However, not all the water resources of the country are accessible because of geographical, topographical and other barriers. This is particularly the case for the abundant water resources in the southwest part of the country, which are generally not accessible for other regions.

Table 3 provides the regional level information on net virtual water export and water resources conditions. The data of water resources (WR) and water resources per capita (WR/cap) are the average values of 2002-2008 (China Statistical yearbook 2003-2009). The regional net virtual water export (NVWE) is the summation of the corresponding provincial results shown in Table 2. Looking into individual regions, the situation differs largely. In the HHH region (Huanghe-Huaihe-Haihe region), which is extremely water 
scarce, the net virtual water export is about $8.0 \%$ of the water resources of the region. $17.3 \%$ of China's net virtual water export is from this region. Hence, the impact of China's international trade on its water resources is much more significant when reviewed at the regional level.

It should be pointed out that a country or region's international trade occurs for multiple reasons, including economic development, political motivation, social consideration, historical trend, natural endowments (apart from water), technology, etc., rather than the water resources concern only. Even for the water sufficient regions, it is imprudent to claim that virtual water export is laudable because of the needs to consider trade-offs between the economic well-being and the state of the environment. The results from this study indicate that it is important to incorporate international virtual water trade into the strategic water and trade planning in China, particularly for the regions with severe water scarcity.

\subsection{Impact of the international trade on water uses}

According to the Chinese statistics, the total water use in China is $5.5 \times 10^{11} \mathrm{~m}^{3} \mathrm{yr}^{-1}$. The net virtual water export of $4.8 \times 10^{10} \mathrm{~m}^{3} \mathrm{yr}^{-1}$ accounts for $8.6 \%$ of the total water use. In other words, $8.6 \%$ of the water use in China is for the production of goods and services for export. For individual provinces, variations are significant (Fig. 5). It is noticeable that some water scarce provinces, such as Beijing, Tianjin, Jiangsu, Shandong, have large shares. In Tianjin, an extremely water scarce area with the water resources of $36 \mathrm{~m}^{3} /$ capita, $63.4 \%$ of the water use is "exported" in the form of virtual water. In Beijing and Shandong, the shares are $17.2 \%$ and $20.2 \%$, respectively. Hence, the virtual water export in these provinces has significant impact on their water uses. With strong export-driving growth mode, it is expected that water demand will continue to increase, putting further pressure on their already stressed water resources.

The total water use for meeting the domestic final demand in China is $4.0 \times 10^{11} \mathrm{~m}^{3} \mathrm{yr}^{-1}$ based on the data in 2002 (Table 1) and the total water use is approximately $5.5 \times 10^{11} \mathrm{~m}^{3} \mathrm{yr}^{-1}$ in 2002 (China Statistical Bureau, 2003). The gap is $1.5 \times 10^{11} \mathrm{~m}^{3} \mathrm{yr}^{-1}$. This means that China uses about $37.5 \%$ more water than that required by its people for the final demand. Subtracting the net virtual water export of $4.8 \times 10^{10} \mathrm{~m}^{3} \mathrm{yr}^{-1}$, there is a missing amount of $10.2 \times 10^{10} \mathrm{~m}^{3} \mathrm{yr}^{-1}$ in the national water balance. This is about $18.5 \%$ of the total water use of the country. The "missing" water may be partly attributed to treated water and water loss during the supply and use. Even when the statistical errors and lumping errors are considered, the unproductive losses are still expected to be significant. Hence, reducing losses in the overall water management and water supply system could make a significant contribution to the alleviation of water stress in China.

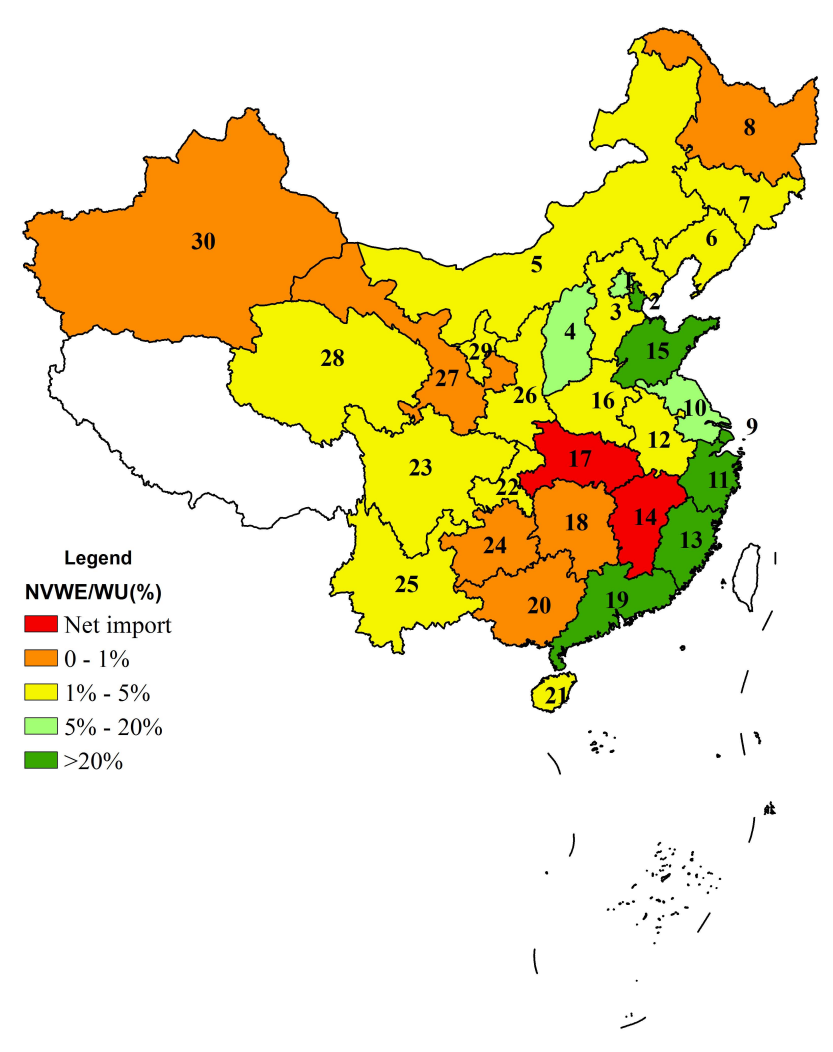

Fig. 5. Share of net virtual water export in total water use in different provinces (2002).

\subsection{Sectoral scrutiny}

The net virtual water export is highly concentrated in Sector 4 (textile goods), Sector 5 (clothing), Sector 14 (electrical goods and communication equipments) (Fig. 1). The three sectors account for $61.7 \%$ of total net virtual water export of the country. These sectors are typically labor intensive, which employ a large number of rural migrant workers. In terms of water use, Sector 4 and Sector 5 are water intensive with high TWUC in their whole production chain. As shown in Sect. 3.3, the share of these sectors is high in water scarce provinces. The results suggest that the international trade patterns and structure of the whole country and individual provinces have been shaped mainly by other factors, rather than water resources endowments.

The study finds that the agriculture sector is a net importer of virtual water at the national level, which is consistent with the results in other studies (Hoekstra and Hung, 2002; Zhao et al., 2009). However, it is not the case for all the provinces. Our study reveals that provinces like Fujian, Anhui, Hubei, Hunan, and Sichuan are net exporters in the agricultural sector.

It is worth noting that food and tobacco processing, textile, and clothing are typical downstream industries of agriculture, i.e. using raw materials from agriculture in the initial stage of 
Table 3. Net virtual water export (NVWE) and water resources (WR) in different regions (2002).

\begin{tabular}{|c|c|c|c|c|c|}
\hline Regions & Provinces & $\begin{array}{r}\text { WR/cap } \\
\mathrm{m}^{3} / \text { person }\end{array}$ & $\begin{array}{r}\text { WR } \\
10^{6} \mathrm{~m}^{3} \mathrm{yr}^{-1}\end{array}$ & $\begin{array}{r}\text { NVWE } \\
10^{6} \mathrm{~m}^{3} \mathrm{yr}^{-1}\end{array}$ & $\begin{array}{r}\text { NVWE/WR } \\
(\%)\end{array}$ \\
\hline North & Beijing, Tianjin, Hebei, Shanxi, Shandong, Henan & 331 & 103251 & 8235 & $8.0 \%$ \\
\hline Northeast & Liaoning, Jilin, Heilongjiang & 1196 & 128114 & 935 & $0.7 \%$ \\
\hline East and Middle & Shanghai, Jiangsu, Zhejiang, Anhui, Jiangxi, Hubei, Hunan & 1696 & 624501 & 17986 & $2.9 \%$ \\
\hline South & Fujian, Guangdong, Hainan, Guangxi & 2977 & 504562 & 18396 & $3.6 \%$ \\
\hline Southwest & Chongqing, Sichuan, Guizhou, Yunnan & 2979 & 594356 & 972 & $0.2 \%$ \\
\hline \multirow[t]{2}{*}{ Northwest } & Inner Mongolia, Shaanxi, Gansu, Qinghai, Ningxia, Xinjiang & 2198 & 256101 & 1122 & $0.4 \%$ \\
\hline & Total & 1737 & 2210886 & 46628 & $2.1 \%$ \\
\hline
\end{tabular}

Data source for WR/cap and WR: China Statistical yearbook 2003-2009

their production processes. Although the agricultural sector is a net importer in China, its downstream industries are not (Table 1). The situation suggests that part of the imported virtual water from agriculture is re-exported through the exports of products in the downstream sectors.

The international trade partners in China contribute to its sober water situation not only in quantity, but also in quality. The wastewater discharge from food and tobacco processing, textile, clothing, paper and products, and metal smelting and products accounts for $53 \%$ of China's total industrial wastewater discharge (China Statistical Bureau, 2009). Small scale and low technology are the common features of enterprises in these sectors, and they are notorious for releasing heavily polluted waste water often without any treatment (Wang et al., 2008). In essence, China is exporting a large amount of virtual fresh water to other countries while at the same time keeping heavily polluted water to itself. The results suggest that China's economic gains from being a world "manufacture factory" have been attained at a high cost to its water resources and through pollution to its environment.

\subsection{Remarks}

It is worth noting that our estimate of the total net virtual water export of China is almost double of the volume estimated by Zhao et al. (2009), which was $2.4 \times 10^{10} \mathrm{~m}^{3} \mathrm{yr}^{-1}$ in 2002 . The difference stems primarily from the regional discrepancy incorporated in the assessment process. Regional discrepancy in TWUC was not considered in Zhao's study, while partly considered in ours as specified in Eqs. (9) to (13). Besides, Zhao's result was obtained based on the national Inputoutput table, whereas this study is a provincial-level analysis using the provincial Input-output tables in which the regional technology variations are embodied. This difference indicates the importance to take into consideration the regional discrepancies in the virtual water trade assessment.

Despite the effort to incorporate regional discrepancies, some limitations remain. Due to data constraint, the assessment does not fully differentiate the regional discrepancy in water use efficiency. As shown in Eq. (7), the regional
TWUC variation consists of regional technology variation reflected by Leontief inverse matrix $\left[b_{i j}\right]$ and regional water intensity variation reflected by DWUC $\left(\omega_{j}\right.$.). In this study, the national average DWUCs for individual sectors are used for all the provinces due to the unavailability of provincial DWUC data. This may cause overestimations of the virtual water embodied in the products from the provinces with higher water use efficiency, and underestimations of the virtual water embodied in the products from the provinces with lower water use efficiency. Therefore, lack of this information makes it difficult to exactly quantify the overall impact on the national virtual water trade figures.

\section{Conclusions}

This study quantifies the virtual water flows associated with China's international trade in an input-output framework. The analysis is scaled down to the provincial level to specify the impact of virtual water trade of individual economic sectors on water resources and uses across provinces.

The results show that China is a net virtual water exporter of $4.8 \times 10^{10} \mathrm{~m}^{3} \mathrm{yr}^{-1}$, accounting for $2.1 \%$ of its renewable total water resources and $8.6 \%$ of the total water use. The impact of China's international trade on its water resources is much more significant when reviewed at the regional level. Water scarce regions tend to have higher percentages of virtual water export relative to their water resources and water uses. In the water scarce $\mathrm{HHH}$ region, the net virtual water export accounts for $8.0 \%$ of the region's water resources and $11.3 \%$ of its water uses. For individual sectors, major net virtual water exporters are those where agriculture provides raw materials in the initial process of the production chain. The results suggest that China's economic gains from being a world "manufacture factory" have been attained at a high cost to its water resources.

This study is a first attempt to use the input-output model to investigate the virtual water flows associated with China's international trade of goods and services with regional specifications. The accounting process used here adopts some 
assumptions due to data constraint. Besides, the quality of the data from the official statistics can also affect the accuracy of the results. Improvements would need more reliable data on the regional disparity of water use efficiency and the information on wastewater discharge, intensity and treatment.

Acknowledgements. We would like to acknowledge the financial support of the Sino-Swiss Science and Technology Cooperation project (SSSTC project) (Grant No. EG 24-092009) and the support of the CAS/SAFEA International Partnership Program for Creative Research and Innovation from the National Natural Science Foundation of China (\#70921061).

Edited by: N. Basu

\section{References}

Allan, J. A.: Fortunately there are substitutes for water otherwise our hydro-political futures would be impossible, ODA, Priorities for water resources allocation and management, ODA, London, 13-26, 1993.

Bouhia, H.: Water in the Macro Economy: Integrating Economics and Engineering into an Analytical Model, Ashgate Publishing Limited, Aldershot, UK, 2001.

Chapagain, A. K. and Hoekstra, A. Y.: The global component of freshwater demand and supply: an assessment of virtual water flows between nations as a result of trade in agricultural and industrial products, Water. Int., 33, 19-32, 2008.

China State Statistical Bureau: China Statistical Yearbook, China Statistics Press, Beijing, China, 2003-2009.

Dietzenbacher, E. and Velazquez, E.: Analysing Andalusian virtual water trade in an input - Output framework, Reg. Stud., 41, 185196, 2007.

Falkenmark, M. and Rockström, J.: The new blue and green water paradigm: breaking new ground for water resources planning and management, J. Water Resour. Plan. Manag., 132(3), 129-132, 2006.

Guan, D. and Hubacek, K.: Assessment of regional trade and virtual water flows in China, Ecol. Econ., 61, 159-170, 2007.

Hoekstra, A. Y. and Chapagain, A. K.: Water footprints of nations: water use by people as a function of their consumption pattern, Water. Resour. Manag., 21(1), 35-48, 2007.

Hoekstra, A. Y. and Hung, P. Q.: Virtual water trade: a quantification of virtual water flows between nations in relation to international crop trade, Value of Water Research Report Series No. 11, UNESCO-IHE, Delft, The Netherlands, 2002.

Hoekstra, A. Y. and Hung, P. Q.: Globalization of water resources: international virtual water flows in relation to crop trade, Global. Environ. Chang., 15, 45-56, 2005.
Hoekstra, A. Y., Chapagain, A. K., Aldaya, M. M., and Mekonnen, M. M.: Water Footprint Manual State of the Art 2009, Water Footprint Network, Enschede, The Netherlands, 2009.

Hubacek, K. and Sun, L.: Economic and societal changes in China and their effects on water use: a scenario analysis, in: Consumption and the Environment, edited by: Hertwich, E., J. Ind. Ecol., 9, 1-2, 2005.

Leontief, W.: The Structure of the American Economy, Oxford University Press, 1941.

Liu, J. G., Zehnder, A. J. B., and Yang, H.: Historical trends in China's virtual water trade, Water. Int., 32, 78-90, 2007.

National Bureau of Statistics of China, China Regional Input-output table 2002, China Statistics Press, 2008.

Oki, T. and Kanae, S.: Virtual water trade and world water resources, Water. Sci. Technol., 49, 203-209, 2004.

River Basin Water Conservancy Commissions: Water Resources Bulletin - Haihe, Huaihe, Yellow River, Yangzi River, Pearl River, Songliao, available at: www.mwr.gov.cn (last access: 1 September 2011), 2008.

Wang, M., Webber, M., Finlayson, B., and Barnett, J.: Rural industries and water pollution in China, J. Environ. Manage., 86, 648-659, 2008.

Wang, Y. and Wang, H. R.: Sustainable use of water resources in agriculture in Beijing: problems and countermeasures, Water Policy, 7, 345-357, 2005.

Yang, H. and Zehnder, A. J. B.: Water scarcity and food import: A case study for southern Mediterranean countries, World. Dev., 30, 1413-1430, 2002.

Yang, H. and Zehnder, A.: "Virtual water": An unfolding concept in integrated water resources management, Water. Resour. Res., 43, W12301, doi:10.1029/2007WR006048, 2007.

Yang, H., Reichert, P., Abbaspour, K. C., and Zehnder, A. J. B.: A water resources threshold and its implications for food security, Environ. Sci. Technol., 37, 3048-3054, 2003.

Yang, H., Wang, L., Abbaspour, K. C., and Zehnder, A. J. B.: Virtual water trade: an assessment of water use efficiency in the international food trade, Hydrol. Earth Syst. Sci., 10, 443-454, doi:10.5194/hess-10-443-2006, 2006.

Zhao, X., Chen, B., and Yang, Z. F.: National water footprint in an input-output framework-A case study of China 2002, Ecol. Model., 220, 245-253, 2009.

Zhao, X., Yang, H., Yang, Z. F., Chen, B., and Qin, Y.:, Applying the Input-Output Method to Account for Water Footprint and Virtual Water Trade in the Haihe River Basin in China, Environ. Sci. Technol., 44(23), 9150-9156, 2010.

Zimmer, D. and Renault, D.: Virtual water in food production and global trade: review of methodological issues and preliminary results, in: Virtual water trade, Proceedings of the international expert meeting on virtual water trade, edited by: Hoekstra, A. Y., Delft, The Netherlands, Res. Rep. Ser. No. 12, 2003. 